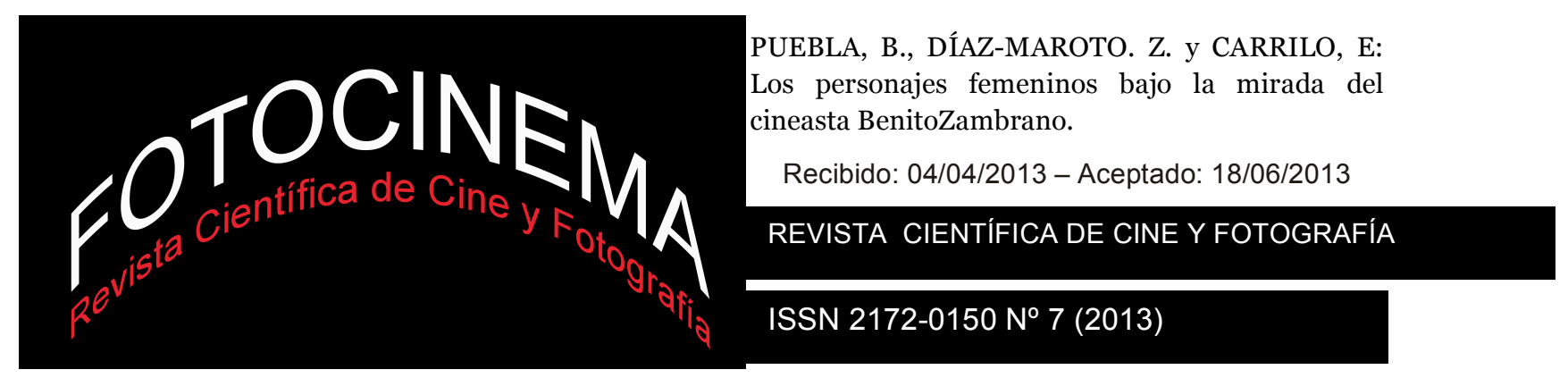

\title{
LOS PERSONAJES FEMENINOS BAJO LA MIRADA DEL CINEASTA BENITO ZAMBRANO. RETRATO DE LA MUJER EN SOLAS, HABANA BLUES Y LA VOZ DORMIDA
}

\section{FEMALE CHARACTERS SEEN BY FILMMAKER BENITO ZAMBRANO. A PORTRAIT OF WOMEN IN THE FILMS SOLAS, HABANA BLUES AND LA VOZ DORMIDA}

\section{Belén Puebla Martínez Zoila Díaz-Maroto Fernández-Checa Elena Carrillo Pascual Universidad Rey Juan Carlos}

\section{Resumen:}

El cine, entendido como productor de imágenes y significados concretos se convierte en un medio esencial para comprender el mundo que nos rodea. Es decir, el cine debe entenderse como un espejo que reelabora la propia realidad de la que se nutre, creando nuevas representaciones que pasarán a formar parte de nuestro imaginario.

En este sentido, este trabajo tiene como objetivo analizar la representación de la mujer en el cine del director español Benito Zambrano. Para ello, no sólo nos hemos centrado en observar los estereotipos que representan los personajes femeninos, sino que hemos analizado la existencia de representación femenina en cada uno de los film a través del test de Bedchel.

De esta forma, hemos podido ver como en sus tres películas (Solas, Habana Blues y $L a$ voz dormida) el cineasta muestra a mujeres que adquieren un mayor protagonismo en cada una de las historias a través de personajes de gran complejidad. Zambrano ha intercalado roles clásicos -madre, hija, esposa- con estereotipos que nada tienen que ver con los que veíamos en el cine patriarcal. Como resultado, nos encontramos con personajes mucho más independientes, fuertes y maduros que se alejan, en cierto modo, del clasicismo de la imagen femenina que pudiera estar integrado dentro del imaginario colectivo.

\begin{abstract}
:
Cinema, understood as the generator of images and meanings, becomes an essential way of understanding the world around us. Moreover, cinema should be seen as a mirror that reworks the reality from which it draws its inspiration, creating new representations that will become part of our imagination.

In this sense, the aim of this article is to analyze the representation of women in the films of Spanish director Benito Zambrano. For this purpose, we have focused not only on observing stereotypes portraying female characters, but we have also discussed the existence of female representation in each of them through the Badchel test.

Consequently, we see that in his three films (Solas, Habana Blues and La voz dormida) the filmmaker shows women taking on more important roles in each of the stories through the complexity of their characters. To achieve this, Zambrano has interspersed classical models -mother, daughter, wifewith stereotypes that have no relationship with what is seen in patriarchal movies. As a result, we find characters who are much more independent, stronger and more mature. In a certain manner, they distance themselves from the classicism of the female image that one would normally find integrated within our collective imagination.
\end{abstract}

Palabras clave: Benito Zambrano; cine; representación femenina; mujer; personaje.

Keywords: Benito Zambrano; cinema; female representation; woman; character. 


\section{Introducción}

Para comprender la evolución de la representación de la mujer en el cine, es necesario remontarse a la década de los setenta, momento en el cual surgió la relación entre la teoría del cine y los estudios de género, a través de disciplinas que iban desde el estructuralismo, la semiótica, el psicoanálisis o la sociología. En esta época destacan autoras como Ann Kaplan, Molly Haskel o Laura Mulvey, cuyo objetivo fue, por un lado, revelar la situación de las mujeres en el cine así como su representación, y por otro, denunciar la ausencia de éstas en el mundo cinematográfico en general.

En los años setenta aparecieron, a ambos lados del Atlántico, los primeros estudios de autoras feministas cuya preocupación se centraba en el análisis del cine como medio cultural. En esos años se van a publicar en Estados Unidos tres libros de crítica feminista de cine dedicados a examinar el papel que ocupa la mujer en el cine clásico: Popcorn Venus: women, movies and the American dream (1973) de Marjorie Rosen, From Reverence to Rape (1974) de Molly Haskell, y Women and their sexuality in the new films (1974) de Joan Mellen. Haskell y Rosen se ocuparán de Hollywood, mientras que Mellen lo hará del cine europeo. Por la misma época comenzó a desarrollarse en Gran Bretaña un acercamiento diferente a la teoría feminista del cine. Así, según Kaplan (1977, p. 394) teoría feminista del cine en Gran Bretaña quería primeramente desarrollar una posición teórica basada en una investigación más profunda de la naturaleza del cine, mientras que la postura americana era menos analítica y más descriptiva.

El objetivo de estos primeros trabajos era "hacer visible lo invisible (...). Estos aspectos consisten no sólo en presencias -las formas explicitas en que representan a las mujeres, los tipos de imagen, los papeles otorgados en las películas-, sino también en las ausencias -las formas en que las mujeres no aparecen en absoluto en las películas o no están en cierto modo representadas en ellas-" (Khun, 1991, p. 87). Aunque como dice la autora, también hay que tener en cuenta el contexto, la realización, y otros aspectos relacionados con la propia película. 
Estas ideas se dividieron en dos corrientes. Por un lado, la corriente teórica y más radical, que se centraba en la cuestión de la imagen de la mujer en el cine y profundizaba en los estereotipos de mujer propuestos desde los orígenes del cinematógrafo, el llamado, a partir de entonces, cine patriarcal (Guarinos, 2008, p. 93). En este sentido destacó Molly Haskell quien construyó una tipología de personajes través del análisis de los estereotipos femeninos que las películas proponían. En su obra From Reverence to Rape (1987) la autora analiza los estereotipos más usuales que iban desde la vampiresa de los años veinte a la víctima de la violencia masculina propia de los años sesenta y setenta. Para Molly Haskell existe una relación directa o inversa "entre las imágenes de la mujer que ofrece el cine y su estatus social" (Kuhn, 1991, p. 89). Haskell destacó la existencia de dos estereotipos dominantes que no tenían mucho que ver con las identidades reales de la mujer: la mujer buena, enclaustrada en el espacio doméstico, maternal y que vivía por y para su familia; y la mujer mala, de dudosa reputación cuyo destino como afirma Parrondo (1995, p. 11) era "convertirse en buena a través del amor romántico y el matrimonio con el héroe; o bien [...] era castigada con ceguera, parálisis o incluso la muerte”.

Por otro lado, surgió la vertiente sociológica, cuyo objetivo se centró en buscar evidencias de la existencia de la mujer en el mundo del cine y denunciar que fueron muchas las figuras del cine olvidadas por los libros de historia.

Posteriormente, en la segunda fase, la teoría feminista estuvo muy influida por la semiótica y el psicoanálisis a través de autores como Lacán o Freud. Su principal representante fue Laura Mulvey, cuyas ideas fueron plasmadas en la obra Placer visual y cine narrativo (1975). En su obra, la autora se basa en la utilización de las teorías psicoanalíticas y semióticas como herramientas para "descifrar y descodificar imágenes de mujeres que enmascaran otros significados, y sobre todo, el difícil discurso de la sexualidad” (1995, p. 66). De esta manera, Mulvey sostiene que la teoría fílmica feminista surgió debido a que la imagen de la mujer que aparecía en el cine no decía nada sobre ella, sino que representaban únicamente la ansiedad de la psique patriarcal, es 
decir, en palabras de la autora, "la mujer sostiene la mirada, representa y significa el deseo masculino" (Mulvey, 1975, p. 9).

En este sentido, la mujer es un fetiche que se ofrece al sujeto observador con el principal fin de introducir a éste en la narración:

En el cine dominante se combinan claramente espectáculo y narrativa. La presencia de la mujer es un elemento indispensable del espectáculo en los films narrativos corrientes, aunque su presencia visual tiende a funcionar contra el desarrollo de una línea argumental, congelando el flujo de la acción en momentos de contemplación erótica. Esta presencia extraña debe ser integrada coherentemente con la narrativa (Mulvey, 1975, p. 9).

En definitiva, el placer del cine clásico de Hollywood se basa en lo que el psicoanálisis llama voyeurismo y fetichismo ${ }^{1}$. El cuerpo de la mujer ya no era simplemente un objeto de deseo y fascinación para los hombres, sino que también era objeto de angustia, ya que el hombre se sentía amenazado por el deseo que la mujer despertaba en él (Parrondo, 1995, p. 12).

En contraposición a estas ideas, Teresa de Lauretis (1987) negó este juego dicotómico entre el voyeur y el fetiche. Lauretis criticó las ideas de Mulvey ya que ésta negaba a las mujeres el acceso al placer de ver el cine. Con estas ideas, se volvió de nuevo a los estudios sociales y políticos que habían caracterizado la primera etapa, así como al uso de la semiótica y el estructuralismo planteados en esta época.

El paso de la década de los setenta a los ochenta significó el comienzo de la crítica de la representación de la mujer, la cual se entendía ya como una representación basada en la deconstrucción de género. Posteriormente, hacia finales de los ochenta, la teoría fílmica feminista gozó de un gran desarrollo. Ya en los noventa, se inició un debate teórico alrededor del concepto de género impulsado, en gran medida, por autoras tan influyentes como Butler (1990) o Haraway (1991). Gracias a este debate, el discurso del feminismo se

\footnotetext{
${ }^{1}$ Según Parrondo (1995, p. 11), el voyeurismo es el placer de mirar sin ser visto y el fetichismo consiste en sexualizar una parte del cuerpo o del vestuario de la mujer con objeto de ocultar/revelar el hecho de la diferencia sexual.
} 
conjugó como una verdadera teoría gracias a la cual se podía entender a la mujer como un sujeto múltiple y además, relacionar el género más allá de la diferencia sexual.

Concluyendo, en las últimas décadas el área de estudio de la teoría feminista y la teoría fílmica se ha ido desarrollando de forma paulatina, ampliando sus métodos y teorías. Ya no sólo existe una preocupación por el análisis textual de la imagen de la mujer en el cine, sino que se tienen en cuenta otros aspectos como son, según Laguarda (2006, p. 12), "la intertextualidad, las transformaciones y transposiciones entre géneros, el abordaje de los aspectos institucionales del cine, y los procesos de enunciación, entre otras cuestiones".

\section{La construcción del personaje femenino en el cine}

Desde los orígenes de la crítica cinematográfica feminista hasta nuestros días se han superado ciertos determinismos feministas y se han incluido en el análisis herramientas tales como el contexto histórico, social y cultural.

Como indica Guarinos (2008, p. 102), si partimos de la base de que "el cine patriarcal no hace representación de la mujer, en tanto que la esquematiza hasta convertirla en un estereotipo, más rol que persona” se puede decir que es más “una imagen más que una representación”. Por tanto, el personaje es construido desde tres niveles: como persona, como rol y como actante.

Como persona, el personaje va a cimentar una iconografía acorde con su estatus social, económico, cultural, con su forma de hablar y su evolución psicológica. Pero los personajes femeninos del cine patriarcal van a estar más desarrollados iconográficamente que psicológica o socialmente. (Guarinos, 2008, p. 102). Al ser consideradas como objetos hechos para la exposición a la mirada, lo que se va a observar es su evolución física, no la psicológica. Va a ser en el cine de los años ochenta y noventa cuando empecemos a ver personajes femeninos protagonistas, ricos, consecuentes con sus actos. Así, por ejemplo, en Hola, ¿Estás sola? (Itcíar Bollaín, 1995) o Princesas (Fernando León de Aranoa, 2005) se muestran, a través de personajes 
femeninos, itinerarios psicológicos de mayor complejidad relacionados con el viaje iniciático que conduce a la madurez psicológica (Guarinos, 2008, pp. 103-104).

En esta evolución de los personajes femeninos también se ha producido, a partir de los años noventa, el fenómeno de la masculinización. Al otorgar al cuerpo femenino un comportamiento masculino, el cine patriarcal comercial ha terminado en la creación de otro estereotipo más. El mejor ejemplo lo encontramos en la evolución de las chicas Bond (Guarinos, 2008, p. 104). En el caso de España podemos destacar el personaje de Hipatia en Agora (Alejandro Amenábar, 2009), un personaje que "en realidad piensa y actúa como un hombre en un mundo de hombres y que busca en la imagen de su padre esta identidad" (Puebla y Carrillo, 2012, p. 10).

Como rol, la vida funcional de la mujer personaje es estereotípica. Como es sabido, los estereotipos de género son generalizaciones y creencias consensuadas sobre las diferentes características y roles de hombres y mujeres. Es frecuentemente compartido por un colectivo y descansa sobre una idea preconcebida, que va a condicionar las opiniones de las personas y dirigir las expectativas de un grupo social. (Ferrer y Bosch, 2003, p. 140). Aunque el cine va a usar los estereotipos por una simple cuestión de funcionalidad narrativa, tenemos que tener en cuenta que los estereotipos se pueden llegar a convertir en prototipos, en modelos de comportamiento, como los que denominó Haskell (1987): la vamp, la virgen, la madre, la mujer profesional o la chica buena.

Según Casetti y di Chio (2010, p. 64) -a partir de las ideas de Greimas (1982) - el personaje como actante ha de entenderse como "un elemento válido por el lugar que ocupa en la narración y la contribución que realiza para que ésta avance”. El personaje ya no se define por sus rasgos o por sus roles, si no por lo que le falta o las acciones que lleva a cabo para conseguir lo que le falta. En palabras de Diez Puertas (2006, pp. 173-174) "el relato existe porque un personaje quiere algo o bien carece de algo, ya sea porque lo ha perdido, se lo han arrebatado u otras circunstancias”. 
En este sentido, las mujeres como actantes se sitúan en posiciones limítrofes del modelo actancial de Greimas (1982). Si recordamos las palabras de Mulvey (1975, pp. 9 y 10), ésta afirmaba que la mujer, aunque es un elemento indispensable dentro del espectáculo del cine, funciona en contra de la línea argumental del film, por lo que su 'presencia extraña' debe ser integrada de la forma más coherente con la narrativa. Así mismo, Khun (1991, p. 48) explica como "existe una tendencia en la narrativa clásica de Hollywood a restituir a la mujer a su sitio. Aún más, a menudo es la mujer -como estructura, como personaje o como ambas cosas a la vez- quien constituye el motor del relato, el 'problema' que pone en marcha la acción”. Es decir, las mujeres son "objetos, ayudantes y oponentes, destinadoras y destinatarias de la actuación de otros" (Guarinos, 2008, p. 109), o lo que es igual, son objetos que han de volver 'a su lugar' para que el orden del mundo se vuelva a restaurar.

\section{Metodología del análisis. Estudio de caso del cine de Benito Zambrano}

El objetivo principal de esta investigación es analizar la representación de los personajes femeninos de las películas del director Benito Zambrano-Solas, Habana Blues, La voz dormida-, partiendo del estudio de los modelos de mujer y estereotipos que aparecen en éstas.

Tomando como punto de partida la teoría clásica de análisis de personajes de Casetti y Di Chio (2010, pp. 159-167), y en base al estudio de los roles, las funciones narrativas y sus posiciones dentro del relato fílmico vamos a extraer los rasgos característicos de los personajes femeninos centrando el análisis en ciertos parámetros de observación que nos permitirán saber si estos personajes toman iniciativas y si es así, en qué terreno lo hacen; si las mujeres tienen escenas por sí solas, al margen de su relación con los personajes masculinos; y por último, si los personajes femeninos tienen entre sí relaciones de amistad, cariño y/o ayuda (Arranz et al., 2008, p. 133).

Es decir, vamos a analizar los personajes femeninos desde tres perspectivas: personajes como personas, como roles y como actantes. Como personas, 
teniendo en cuenta sus "comportamiento, reacciones y gestos" (Casetti y di Chio, 2010, p. 159) o lo que es lo mismo, como una unidad de acción y una unidad psicológica; como un rol, partiendo de sus acciones y sus caracteres, así como de los valores que representa, y por último, como actante, teniendo en cuenta la posición que ocupa en el relato.

Por otra parte, someteremos a cada una de las películas al test de Alison Bechdel (1986). Con este test analizaremos la exigencia de un mínimo de representación femenina en el cine de Zambrano. Esta técnica de análisis no proviene de estudios académicos sino de la militancia feminista ${ }^{2}$. En 1985 la viñetista y novelista gráfica Alison Bechdel publicó una historieta llamada Dykes to watch out for 3 , donde desarrolló lo que para ella van a ser las reglas básicas que señalan un mínimo de representación femenina en una película. En una de las viñetas podemos ver a dos mujeres donde una le dice a la otra: "Yo sólo voy a ver una película si satisface tres requerimientos básicos. Uno, debe haber al menos dos mujeres en ella que, dos, hablen una con la otra sobre, tres, alguna cosa aparte de hombres” (Bechdel, 1986). Posteriormente, a estas reglas se le agregó la exigencia de que los dos personajes femeninos tengan un nombre en la película, es decir, que no sea una conversación intrascendental con figurantes. Mediante la aplicación del test de Bechdel vamos a intentar constatar si en las películas de Zambrano hay, realmente, un mínimo de representación femenina.

La elección de las películas de Benito Zambrano no es casual. Su filmografía se caracteriza por narrar historias de la vida cotidiana, con un ingrediente de carácter social y con protagonismo principalmente femenino. Zambrano pone especial cuidado en la construcción de unos personajes que resultan completamente verosímiles, y como él mismo dice:

Aunque sean personajes de ficción, para mí son, casi, como si fueran de verdad, y por eso soy muy respetuoso con su biografía y eso implica muchas cosas: no frivolizar con lo que les pasa, profundizar en sus problemas, tratar de comprenderlos. También porque entiendo que

\footnotetext{
${ }^{2}$ www.bechdeltest.com

${ }^{3}$ Ver anexo 1
} 
hablar de los personajes es, al mismo tiempo, hablar del ser humano, contar historias es eso: como poner un espejo delante de nosotros, un espejo en el que nos identifiquemos (Melini, 2011, p. 52).

\section{Retrato de los personajes femeninos: Solas, Habana Blues, La voz dormida}

En las películas analizadas vamos a encontrar retratos de familias humildes en las que afloran conflictos de diversa índole. Según Lanuza (2012, pp. 7576), "la disgregación familiar y el dolor que provoca la separación es una constante en el cine de Zambrano", aunque siempre abre una puerta a la esperanza en sus obras. Cómo veremos, Caridad en Habana Blues, y María en Solas encarnan la esperanza de un futuro mejor, y Pepita intenta una y otra vez mirar hacia adelante y no quedar anclada al aciago pasado que la rodea.

\subsection{Solas: retrato de una relación madre e hija}

En su primera película, el director español nos cuenta la historia de María (Ana Fernández) y su madre Rosa (María Galiana). María es una mujer alcohólica, sin sueños, y que a sus 35 años malvive gracias a eventuales trabajos como limpiadora en un barrio marginal de Sevilla. Su vida cambia cuando su madre, Rosa, vuelve del pueblo y se instala en su casa una temporada, mientras su padre se recupera de una intervención quirúrgica en la capital andaluza. En ese periodo de tiempo, María descubre que está embaraza, pero el padre del hijo que espera no quiere saber nada del bebé. A partir de ese momento, madre e hija van retomando de nuevo su relación, aunque María no deja de echar en cara a su madre que siga aguantando los maltratos y humillaciones que le ha hecho, y le hace pasar su padre, adicto al juego y alcohólico. Surge entonces un nuevo personaje, el vecino de María, con el cual Rosa inicia una amistad, y quien finalmente se convertirá en el nexo de unión entre las dos mujeres. 
Solas (1999), además de presentarse como el título del film, simboliza también la realidad que intenta representar el director español. Estamos no sólo ante un melodrama, si no ante una producción de corte social que intenta acercarnos a una realidad concreta. Una realidad marcada por el papel de la mujer en la sociedad y de forma particular, dentro de la institución familiar. Por un lado, Zambrano nos traslada a una Sevilla que poco tiene que ver con la identidad cultural trasmitida por otras películas a través de tópicos como el flamenco, los toros o la cultura gitana, sino que nos adentra en "una ciudad contemporánea cualquiera, con sus barrios marginales" (Pino, 1999, p. 11). Por otro, el director nos sumerge en las penurias y problemas de una familia desestructurada, marcada por una madre y unos hijos sometidos a un padre adicto al alcohol y al juego.

En este contexto surgen sus dos protagonistas, aunque en un principio bien pudieran parecer antagonistas ya que representan valores contrapuestos durante gran parte de la cinta. Rosa y su hija María, pertenecen a dos generaciones de mujeres distintas, pero ambas están marcada por la soledad en la que están ancladas sus vidas. Rosa simboliza los valores tradicionales dentro de una sociedad patriarcal, a través del papel de madre protectora y volcada en el cuidado, no sólo de los suyos, sino de todos los que le rodean. Como afirma del Pino (1999, p. 13) "contradice el arquetipo de madre fálica, característico del cine español” y es que, aunque Rosa representa el rol femenino por excelencia -el de madre- éste se aleja de ciertos estereotipos tradicionales que podíamos ver en el cine clásico, tales como la imagen de la madre castradora, que dominaba y coartaba la libertad de sus hijos, o la mater amabilis, esa mujer atada al ambiente doméstico, una ama de casa feliz, maternal y que se desvivía por sus hijos y su marido.

En este sentido, el director nos muestra una mujer que se ajusta más a la imagen de mater dolorosa 4 . La vida de Rosa depende del bienestar de los demás, por lo que su felicidad esta condicionada por la de las personas que le rodean. Ella entiende su existencia en el mundo como una forma de

\footnotetext{
${ }^{4}$ Según Virginia Guarinos (2008, p. 107) "es la madre sufridora que observa cómo sus hijos son maltratados por la vida y que incluso pueden llegar a maltratarla a ella. Es uno de los pocos tópicos de edad madura, rozando la ancianidad".
} 
servidumbre hacia el resto, pero a pesar de que esto pudiera provocar la infelicidad de la protagonista, se resigna a pensar que es lo normal y siente satisfacción cuando ve en los demás la felicidad que ella no puede, ni debe, conseguir. Tal y como afirma Lucía Llorente (2009, p. 2) "Cuidar y querer a su familia es lo que le hace feliz y lo que le hace sentirse realizada y completa”. Son numerosos los ejemplos que ilustran esta actitud de la protagonista en la cinta: recordemos cuando Rosa sólo se aleja de la cama del hospital en la que se encuentra su marido, cuando el médico la obliga a irse a casa a descansar; o cuando le cura las heridas de la mano a su hija, a pesar de que ésta la trate con desprecio y la humille continuamente; o cuando ayuda a su vecino a asearse después de haber pasado una noche enfermo en la cama.

Por su parte, María es una mujer despechada y desengañada por la vida, no confía en ninguna persona y no acepta la ayuda de nadie para poder salir adelante, algo que deja ver a través de frases como "nadie tiene buen corazón”, en la que tacha a su madre de ingenua por confiar en todo el mundo, o "son todos unos hijos de puta", refiriéndose a los hombres, quienes según ella misma afirma, sólo le han hecho daño en esta vida. Rechaza a su familia, especialmente a su padre, por maltratar a su madre y sus hijos; a su madre, por permitir que la maltratase y la sometiese durante toda su vida, y a sus hermanos, por haber podido escapar de ese calvario y por tener más suerte que ella al rehacer sus vidas. Reniega también de sus orígenes campesinos, por eso se refugia en la ciudad, aunque sus expectativas pronto se ven truncadas y malvive gracias a trabajos temporales que no requieren ningún tipo de cualificación. María está enfadada con la vida y se castiga así misma a través de su adicción al alcohol, algo que la mantiene aislada del mundo y no le permite mantener relaciones sociales con nadie. Aún así, mantiene una relación con un hombre casado del cual se queda embaraza y, aunque en un principio piensa abortar, decide tener a su hijo -aunque lo mantendrá en secreto-.

La cinta deja ver además las diferencias entre la vida en el campo y la gran ciudad, algo que se representa a través de los dos personajes protagonistas. Rosa es una mujer del mundo rural que “...vive con su marido una dictadura 
social, anclada en el pasado, la cual todos relacionamos con las costumbres mantenidas mayormente en los pueblos durante el franquismo" (Berrocal, 2006, p. 11). Durante el tiempo que Rosa está en la capital hispalense con su hija, anhela la seguridad y protección que le da el pueblo, mientras que María huye a la ciudad en busca de ese individualismo característico de las grandes urbes, donde cualquiera puede pasar inadvertido y ser transparente a los ojos de la gente. En este contexto, el punto de encuentro y unión entre las dos mujeres será el apartamento en el que vive María en uno de los barrios de la periferia sevillana. Al comienzo de la película, el apartamento se muestra oscuro y sucio -igual que la relación entre madre e hija- y con un fuerte olor a humedad, del cual nos advierte Rosa.

De la misma forma que la relación entre las dos mujeres va transformándose, la imagen del apartamento va cambiando a medida que los lazos entre Rosa y María se van tejiendo -igual que el chaleco que le hace Rosa a su hija, y que le entrega justo antes de volver al pueblo-. La labor de reconciliación entre las dos mujeres recae sobre todo en Rosa, quien a través de gestos y palabras hacen entender a María su situación y su comportamiento durante todos estos años. Así, mientras sus lazos emocionales vuelven a recuperarse, Rosa va recomponiendo el piso de su hija -al igual que su propia vida- con pequeños detalles: algunas plantas que va poniendo en distintos rincones de la casa, una mecedora que recoge de la calle, o incluso un cazo con comida en la lumbre. Todo ello hace que María vuelva a sentir eso que tanto anhelaba, el calor de un hogar o el amor de su propia madre.

Además, cuando el padre de María sale del hospital y Rosa y él vuelven al pueblo, María descubre que su madre le ha dejado en el apartamento una bolsa con algunos recuerdos de una época pasada. Entre estos recuerdos destacan unas fotos de madre e hija en el pueblo, que simbolizan la reconciliación entre ambas, y que Rosa guardó durante todo este tiempo para devolvérselas a su hija, quien ahora se encargará de guardarlas. De esta forma, la relación entre madre e hija vuelve a ser lo que había sido anteriormente, ya que María logra tener las fuerzas necesarias para recordar tiempos pasados junto a su familia, de la que huyo tiempo atrás. 
Durante el desarrollo de la cinta surge la figura de un hombre viudo (Carlos Álvarez-Novoa), que vive solo junto a su perro en el mismo edificio que María. Este personaje es la antitesis del marido de Rosa y el padre de María, y el resto de hombres que han pasado por sus vidas. Él se convertirá en el confidente de las dos mujeres, primero de Rosa mientras está sola en la gran ciudad, y después de María, cuando su madre vuelve al pueblo con su padre. Este hombre será también el nexo de unión entre las dos mujeres cuando estas estén separadas.

Rosa y María representan así las dos caras de la misma moneda. Dos mujeres abandonadas y sometidas por el hecho de ser mujeres, aunque cada una hace frente a ese hecho de distinta forma: Rosa se resigna y sonríe para sí misma sonríe aunque su marido la insulte y sonríe ante los gritos de su hija-, María, en cambio, se enfada con el mundo y llora y bebe hasta emborracharse y olvidarse de todo. Las dos mujeres nos acercan a las diferencias en la condición del ser humano por el hecho de pertenecer a un sexo u otro, o por pertenecer a generaciones distintas, o por pertenecer a dos mundos distintos, aunque en realidad ambas no se diferencian en casi nada. Las dos mujeres representan el estereotipo de heroína, cada una en un momento y en un contexto distinto han tenido que sobrevivir a los infortunios de la vida, muchas veces nacidos de su condición como mujer. Rosa ha tenido que vivir sometida a un hombre toda su vida, mientras que María ha intentado salir de ese túnel sin mucha fortuna. Al final de la película, María logra comprender a su madre y entender por qué ha tenido que actuar así. Gracias a ello, se reconcilia con ella y consigo misma, aliviando todo el dolor que llevaba dentro y comienza una nueva vida en la que intentará ser feliz, por ella y por su madre.

\subsection{Habana Blues: retrato de una ciudad}

Habana Blues (2005) es la segunda película de Zambrano, aunque para él habría sido la primera si hubiera tenido suficiente financiación. Durante los años 1994 y 1996, el director estuvo estudiando en la escuela de cine y 
televisión de San Juan de Baños en La Habana (Cuba). Esa experiencia supuso para Zambrano algo más que conocimientos cinematográficos. Según afirma "allí amé, creé, trabajé, hice muchos amigos y seguramente algún enemigo. Con el tiempo se fueron asentando mis vivencias en ese país donde nunca me sentí extranjero" (Maestranza Films, 2006)5. Y todos estos sentimientos se recogen en esta película. Un film con dos protagonistas indiscutibles, y ninguno de los dos humanos: por un lado, la ciudad y, por otro, la música. Como señala Rueda Palomar (2011, p. 146) "si el esqueleto de la película lo conforma la banda sonora, la consistencia de la misma va a estar a cargo de la ciudad”. Esta afirmación acompaña hasta el título de la cinta, en las que se unen ambas pasiones.

La película narra las vivencias de dos jóvenes, Ruy (Alberto Yoel) y Tito (Roberto Sanmartín). Ambos tienen muy clara su vocación, la música. Sus vidas giran en torno a su grupo de rock underground, aunque con dos posiciones diferentes. Ruy vive como un eterno adolescente -inocente e irresponsable- cuya única satisfacción en la vida es la música; Tito, mucho más pícaro, interesado y materialista, ve la música como una vía de escape para salir de la isla. Con la llegada de unos productores musicales españoles que buscan nuevos ritmos alternativos cubanos (rock, rap, heavy o fusión), se disparan las aspiraciones de ambos. Tito ve por fin una posibilidad real de salir de Cuba, mientras que Ruy va a ver cumplido su deseo de tocar en un teatro. Ambos tienen a su alrededor mujeres que les acompañan y les guían. Podríamos decir, que Ruy y Tito son dos niños grandes que no 'quieren' madurar ya que se sienten arropados por las mujeres que los rodean.

Tres son las mujeres que giran en torno a los dos protagonistas: Marta (Marta Calvó), la productora musical española; Caridad (Yailene Sierra), la mujer de Ruy; y Luz María (Zenia Marabal), la abuela de Tito. Tres mujeres completamente independientes y fuertes, algo de lo que carecen los hombres del film.

\footnotetext{
${ }^{5}$ La declaración de Benito Zambrano está recogida del dossier de prensa con motivo del estreno de Habana Blues. (Maestranza Films, 2006).
}

150 
Marta es una ejecutiva con un talante muy agresivo. Trabaja en una discográfica y llega a la isla en busca de nuevos talentos. Es una mujer completamente entregada a su actividad profesional. Segura de sí misma, inteligente y muy ambiciosa. En ocasiones se muestra poco tolerante y soberbia con quienes desconocen su ámbito de trabajo. Habla a los músicos cubanos con un tono despectivo al comprobar que son posibles víctimas debido a su ignorancia en lo referente a la industria discográfica en los países capitalistas. Además, es capaz de aprovecharse de esa ignorancia de tal forma que ella sea la máxima beneficiaria. Marta es una mujer banal, superficial, fría y calculadora. No le importa la situación real que viven Ruy y Tito en la isla. Al contrario, se vale de esta situación desesperada e intenta sacar el mayor partido. Como ella reconoce "Esto es un negocio. El business es el business". Su aspiración es convencer a los músicos para que firmen un contrato de trabajo que resulta abusivo y una explotación descarada, sin plantearse lo que puede suponer para ellos. Esta estrategia no podría hacerla con cualquiera y busca el punto débil de cada uno para sacarles ventaja. $\mathrm{Su}$ forma de actuar es astuta, aunque puede llegar a convertirse en cruel. Como afirma Rueda Palomar (2011, p. 143) "Marta aparece con todos los matices de un personaje malvado: prepotente, fría, distante, soberbia... que contrastan con la ingenuidad e inocencia, quizá un poco sobreexpuesta, de los músicos cubanos".

A Marta podríamos llegar a compararla con la figura de la femme fatal, aunque no sería el estereotipo prototípico. No hablamos de una mujer hermosa, sexy, sensual ni exuberante. No lleva vestidos elegantes ni ceñidos que marquen su figura. Por el contrario, Marta no tiene un físico llamativo ni espectacular, viste elegantemente pero de una manera discreta. Su atractivo se encuentra en la seguridad que muestra en sí misma y en el poder que demuestra frente a los hombres que la rodean, por un lado su compañero de la discográfica y, por otro, su relación con Ruy y Tito.

Por su forma de ser consigue todo lo que se propone, tanto en el aspecto laboral como en el personal, sin importarle manipular a quien sea para conseguir sus fines. En el aspecto personal, desde el primer encuentro que 
tiene con Ruy se muestra atraída por el músico y como buena femme fatale consigue a su 'presa' en cuanto se lo propone. Es una amante muy activa y apasionada llegando a convertirse en una especie de devoradora de hombres a los que trata a su antojo con el fin de satisfacer sus más bajos instintos. Incluso en los encuentros sexuales que mantiene con Ruy, es Marta la que domina la escena en todo momento. Aún así, continua aprovechando la situación para seguir hablando de trabajo.

Otra de sus señas de identidad son su inteligencia, su carácter marcadamente fuerte y la ausencia de sentimientos. Tan sólo podemos ver dos escenas en las que se vislumbra un ápice de debilidad. En ambas recibe un desplante por parte de Ruy. Pero más que mostrar tristeza por lo sucedido, simplemente actúa con indiferencia. Por ejemplo, cuando Ruy le dice en la playa que no quiere seguir con ella, le contesta después de una pausa: "En fin, me voy a dar un bañito, que no quiero que nadie me estropee esta tarde. Chao" En su interior puede estar muy dolida -en su orgullo sobre todo- pero jamás lo mostrará delante de Ruy ni de nadie. Ella tiene que quedar siempre por encima de cualquier sentimentalismo que haga tambalear su imagen de femme fatale.

En el otro extremo encontramos a Caridad, mujer de Ruy y madre de sus dos hijos. Caridad es una superviviente en todos los aspectos de su vida. Es ella la que se encarga de sacar a su familia adelante. Caridad tiene que dejar de impartir clases en la universidad para dedicarse a la elaboración y venta de abalorios para los turistas porque le resulta económicamente más rentable los abalorios se pagan en dólares y su contrato en la universidad se cobra en la devaluada moneda nacional-.

Su vida se construye en el tedio de una relación que ya está deshecha y en una rutina laboral que dista mucho de ser ideal. Caridad se siente sola, desamparada, incomprendida, encerrada en una vida que no se merece. A su situación laboral y económica precaria se suma su necesidad de libertad, de ser ella misma. Y ante esta situación sabe que no cuenta con el apoyo de Ruy. Aunque ella sigue enamorada de él, entiende que lleva toda su vida renunciando a todos sus sueños por estar a su lado. Como reconoce Ruy en 
una canción que le dedica: "Cada vez te olvidabas más de ti, para apoyar mis sueños, pero sé que lastimé tu corazón, jugando con tus sentimientos”.

Caridad puede ser considerada como una madre coraje y dolorosa. Capaz de enfrentarse a cualquier tipo de vicisitudes por el bienestar de su familia. Porque Caridad no es sólo madre de sus dos hijos, sino que con Ruy también se muestra como una madre protectora y consejera -no olvidemos que Ruy sigue actuando como un adolescente-. Podemos comprobarlo en la escena en la que cura las heridas a Ruy después de su pelea con Tito: "Cada cual tiene que seguir su camino. Tú sin él y yo sin ti”. Ruy es egoísta, no aporta soluciones a la precariedad de la familia, al contrario, deja todo en manos de Caridad que es mucho más sacrificada, resolutiva y adulta que él. Mientras ella se encarga de trabajar, de racionalizar el dinero, de las tareas de la casa, Ruy sólo piensa en su música. Tanto es así que es ella, sin contar con Ruy, la que decide irse con sus hijos en una lancha clandestina a Miami. Son también hijos de Ruy, pero la decisión es unilateral de Caridad: “O me apoyas o te aguantas. También puedes denunciarme. Si no me vas a apoyar no me lo hagas más difícil”. Este hecho hace que Ruy comience a madurar y a darse cuenta de lo que va a perder.

Físicamente, Caridad, aunque es joven y atractiva, no se cuida lo suficiente. $\mathrm{Su}$ aspecto es un tanto desaliñado. Lleva el pelo corto, no se maquilla, viste de manera cómoda, sin preocuparse de su indumentaria -en cambio, como buena 'madre', sí se preocupa, por ejemplo, por la ropa con la que actuará Ruy en el concierto-. Su personaje está más definido por sus rasgos maternales que por sus rasgos femeninos. Ruy ve a Caridad como una madre, una sirvienta, una psicóloga, una amiga y, en contadas ocasiones, como una mujer.

Caridad es una mujer luchadora, fuerte y a la vez sensible. Una mujer llena de esperanza que no parará hasta conseguir una nueva vida con sus hijos. Es sobre todo, una superviviente.

Y, por último, haremos una breve referencia a otro de los personajes femeninos que, aunque secundario, tiene gran peso en la vida de Tito. Luz 
María es la abuela de Tito, quien además vive con ella. Es una entrañable anciana, digna del club del film Buena Vista Social Club (1999) de Wim Wenders, que en su juventud fue una gran cantante y ahora, en su vejez, tiene que sobrevivir impartiendo clases de música a los niños del barrio.

Como Marta y Caridad, Luz María es un personaje fuerte e independiente. Continúa tratando a Tito como si fuera un niño - un hecho que se aprecia en numerosas ocasiones a lo largo de la película-. A Ruy también lo considera como el compañero de juegos de su nieto. Cumple un papel de madre y abuela, por una parte, le regaña en numerosas ocasiones, como una madre que quiere el bien para su hijo y por otra, actúa como la abuela que es, consintiéndole y participando en sus 'juegos' musicales - canta con la banda de su nieto una canción-. Aún así, muestra durante toda la cinta una postura matriarcal. Su tono severo, su actitud frente a la vida, su porte elegante, su afición al ron... son características de una mujer capaz de enfrentarse a cualquier cosa y acostumbrada a las penurias que debe soportar en la isla. $\mathrm{Y}$ así actúa, aconseja a su nieto a que haga lo que quiera hacer sin depender de la decisión de nadie. Es lo que ha hecho ella durante toda su vida. Como dice: "Yo sé valerme por mí misma. Nunca he necesitado a nadie".

En definitiva, en esta película todos los personajes buscan un sueño y descubren el precio que van a tener que pagar por él. Según el eslogan de la cinta: Vivir es elegir. Y si hay personajes que tienen claro durante todo el relato sus elecciones y el sueño que quieren conseguir esas son las mujeres. Como afirma Del Pozo (2005, p. 204) "Caridad, Luz María y Marta no son personajes pasivos y dependientes de los personajes masculinos. Muy al contrario, ellas muchas veces son el motor de la acción, toman decisiones que los personajes masculinos tratan de posponer, son independientes y mantienen su dignidad a pesar de las circunstancias”.

\subsection{La voz dormida: retrato de dos hermanas}

Tras una larga ausencia Zambrano regresa al cine con la adaptación de la novela homónima de Dulce Chacón, La voz dormida (2011). 
La voz dormida es una película de mujeres. La mujer es la protagonista por antonomasia. Aunque nos narra la historia de dos hermanas marcadas por la Guerra Civil y víctimas de la posguerra, la voz coral que se alza y envuelve toda la cinta es un coro femenino. La singular voz dormida que da título, tanto al libro como a la película, es en realidad una voz colectiva y disidente, la de un grupo de mujeres que van configurando esa voz a lo largo de la historia.

En plena postguerra, Pepita (María León), una joven cordobesa de origen rural, viaja a Madrid para estar cerca de su hermana Hortensia (Inma Cuesta) que está embarazada y en prisión. Una vez en la capital, conoce a Paulino (Marc Clotet), un valenciano de familia burguesa que sigue luchando en la sierra de Madrid. A pesar de la dificultad de su relación, ambos se enamoran. Hortensia es juzgada y condenada a muerte, pero su ejecución se pospone hasta después del parto. Pepita luchará por salvar la vida de su hermana e intentará por todos los medios que le entreguen al bebé que va a tener Hortensia para evitar que lo den en adopción o lo envíen a un orfanato.

Las dos protagonistas son las hermanas Pepita y Hortensia. Para analizar ambos personajes hay que partir de que el discurso oficial franquista intentaba fijar una dicotomía dual virtud-pecado, por lo que los modelos arquetípicos de mujer que se ajustaban a la descripción de la mujer de la posguerra eran los de la virgen María y Eva, es decir, el ángel del hogar y la femme fatal. Según Roca i Girona (2003, p. 53), el primer modelo muestra una mujer asexual y espiritual, cuyo cuerpo está libre de cualquier connotación sexual que no sea la función reproductora. Es una mujer “austera, púdica, pasiva y servicial”. El segundo modelo estará inspirado en la estética vamp, según la cual la mujer "constituye un ser sexual, empapado de erotismo, que trasluce libidinosidad, deseo y pasión”. Pepita se adscribiría al primer modelo y Hortensia al segundo, aunque ambos personajes presentan una multiplicidad de matices que los alejan de la representación estereotípica del bien y del mal.

Pepita es una chiquilla de ojos azules y pelo castaño claro. Es la dulzura e inocencia personificadas. Pepita es un alma cándida. Casi siempre va con el 
pelo recogido, viste con recato $^{6}$ y además lleva luto porque a su padre lo fusilaron (“¿los nuestros o los rojos?”, le pregunta Amparo, su señora). De su cuello cuelga una cadena con una medallita (a veces un escapulario para realizar los “encargos”). Es modesta, espontánea y muy inocente. Está llena de generosidad como demostrará a lo largo de toda la película. Destaca en ella sus ganas de vivir y su afán por poner la vista en el futuro y dejar atrás el pasado. Pepita tiene cara angelical. Lo más atrevido que hace es darle un beso a Paulino cuando éste le pide que sea su novia. Podríamos decir que es una chica apegada a los ideales de la época: es modesta, sencilla y religiosa. Ella dice que intenta ser una buena cristiana "voy a misa todos los domingos, confieso y comulgo". Cree que la política le está arrebatando a su familia. A su padre lo mataron porque no encontraron a su hermana, y su hermana está en la cárcel por ser comunista y estar casada con un guerrillero antifranquista.7.

Pero los durísimos acontecimientos a los que tendrá que enfrentarse harán que su personalidad vaya cambiando y se convierta en una mujer fuerte a pesar de su apariencia dulce y frágil. El viaje de Córdoba a Madrid será para Pepita el viaje iniciático de niña a mujer. Pepita llega a Madrid siendo una chiquilla ingenua que poco a poco se irá transformando en una mujer madura. Su proceso de madurez se va a consolidar a partir de su experiencia vital. El punto álgido de este proceso se producirá cuando se convierta en virgen-madre como consecuencia de tener que asumir la maternidad sobrevenida cuyo fruto es su sobrina recién nacida.

A pesar de que no le interesa la política, las circunstancias la obligarán a tomar partido, a tener que arriesgarse para intentar ayudar a su hermana y a su cuñado. Pero su lucha será por amor y no por compromiso político. Cuando se ve involucrada sin quererlo en ayudar a los maquis que están en la

\footnotetext{
${ }^{6}$ La Iglesia católica impuso el modelo de "vestir cristiano" que afectó principalmente a las mujeres: las mangas y las faldas debían ser largas, no podían usarse escotes, ni vestidos ceñidos, ni pantalones, puesto que se consideraban una prenda masculina. (Domínguez, 2003, p. 205).

${ }^{7}$ La captura y encarcelamiento de las mujeres funcionaba como una operación de chantaje y castigo destinada a los hombres. Era frecuente que al no encontrar al marido o al padre, la policía franquista se llevara presa a la mujer, a la madre, a la hija o a la hermana (Hernández, 2003, p. 115). Así en la película, Amalia (amiga de Hortensia que no está en la cárcel) le dice a Pepita que "las cárceles y las fosas están llenas de gente que nunca tuvieron ideas políticas".
} 
sierra, entre ellos su cuñado, se muere de miedo, no se cree capaz, y le dirá a su hermana: "Tensi, por favor no me pidas eso, tú sabes que yo no tengo sangre 'pa' esas cosas, tú sabes que si a mí me cogen yo lo digo 'to'”. Pero sus vivencias la irán haciendo fuerte, llegando al límite cuando es arrestada y torturada soportando las degradaciones y el sufrimiento sin delatar a nadie.

En el personaje de Pepita se produce, en cierto sentido, una subversión del rol de género tradicional según va avanzando la película. Si sus cualidades iniciales eran las que el sistema patriarcal atribuía al ideal de mujer: timidez, pasividad, desvinculación política, inocencia y lealtad; además de excelente costurera, buena cristiana, etc. Pero a medida que avanza la historia, veremos aparecer en ella atributos considerados tradicionalmente como masculinos, como su valentía y su determinación y coraje. (Oaknin, 2009/2010, p. 16).

La otra hermana es Hortensia. Hortensia es una mujer joven. Está embarazada de siete meses al inicio de la cinta. Es morena, ojos grandes y negros; perfilan su rostro unos labios carnosos. Tiene una melena larga y rizada, a veces la lleva suelta y otras recogida en una trenza. Es sensual, atractiva y coqueta. Representa la imagen de lo que los franquistas llamarían miliciana desgreñada y podría ser clasificada como una femme fatale por su aspecto físico. Es resuelta, atrevida, y además, posee un fuerte carácter. Este nuevo modelo femenino correspondía a la mujer joven y heroica que trabajaba por la causa republicana. Su imagen más representativa, como dice Domínguez (2003, p. 192) será "la miliciana, que será convertida en una imagen-mito", admirada por los republicanos y vilipendiada por el nuevo régimen.

Pero Hortensia, o Tensi como la llama casi todos los que la quieren, también es una mujer idealista, una heroína que mitifica y exalta la causa republicana. Ella es capaz de perder su libertad en defensa de sus ideales, sin doblegarse y sin que se disipe su entereza en ningún momento. Está muy concienciada y comprometida políticamente (pertenece al Partido Comunista). Nunca flaquea ante la adversidad. Es combativa, por eso sigue trabajando por la causa dentro de la cárcel. Hortensia será sometida a un juicio sumarísimo en el que no tendrá ninguna posibilidad de defenderse. Representa una 
resistencia activa y lucha por unos ideales de justicia y libertad. Hortensia muestra un fuerte aplomo frente a las circunstancias negativas que la rodean, y en todo momento, a pesar de su embarazo e inminente maternidad, presenta una gran integridad.

El personaje de Hortensia es también poliédrico. Por un lado tiene una enorme fuerza y determinación; por otro lado, el amor y la fidelidad que siente por Felipe (Daniel Holguín), su marido, hacen de ella una heroína romántica, y en cierto modo destruye alguno de los tópicos de la mujer guerrillera. (Oaknin, 2009/2010, p. 16). Aún así, a pesar de la ternura que demuestra hacia su hija, mantendrá sus firmes convicciones como su negativa a que bauticen a su pequeña.

Otros personajes femeninos dignos de mención son, por un lado, doña Celia, que regenta la pensión donde vivió Hortensia y donde vive ahora Pepita. Esta mujer sufre su drama personal por la desaparición de su hija. Y por otro, doña María que da refugio en su casa a miembros de la guerrilla poniendo en peligro su propia vida.

Junto a Hortensia, conviven en la cárcel Elvirita, la más joven; Sole -una miliciana muy activa-, Remedios -que está intentado aprender a escribir-, Carmenchu, o Tomasa. La mayoría de ellas van a formar una red clandestina de resistencia y solidaridad, contactando con el exterior para colaborar y ayudar a la resistencia. Las vemos organizando reuniones, repartiendo octavillas, e incluso desafiando continuamente a sus carceleras, como cuando cantan la Internacional, o se niegan a besar la figura del Niño Jesús, a pesar del altísimo coste humano que suponía para ellas. (Oaknin, 2009/2010, p. 12). Por eso la sonoridad de sus voces cuando cantan al unísono en la cárcel conmueve extremadamente al espectador.

Zambrano nos muestra a unas mujeres que reivindican su identidad en contraste con la imagen prototípica de la mujer que permitió el franquismo: esposa sin estudios, madre sumisa y devota, y sin vinculación política alguna. Las funcionarias de prisiones, los representantes de la iglesia católica y los partidarios del régimen, salvo algunas excepciones, salen muy mal parados 
en la película. Por ejemplo, las monjas de la prisión se presentan como seres hipócritas e insensibles a las necesidades de las presas. Esto le sirve al director para generar en el espectador la sensación de desprecio y rabia que necesita, aunque esto provoca una definición un tanto maniquea y plana de los personajes integrantes del bando nacionalista, y quizá le resta un poco de verosimilitud a la historia.

Se salva de esta caracterización, por un lado, doña Amparo, la señora de la casa donde trabaja Pepita de criada, la cual muestra cierto grado de compasión hacia Pepita haciéndola partícipe del dolor que ella también siente por la pérdida de sus dos hermanos pequeños. Y por otro, el personaje de Mercedes, la única de las funcionarias de la prisión que muestra cierta humanidad con las reclusas, y que intentará ayudar en la medida de sus posibilidades a Hortensia.

Para concluir, podemos decir que la película logra despertar una identificación afectiva y emocional en el espectador hacia esas mujeres luchadoras. Son las mujeres las que mueven los hilos de la trama, mientras que los hombres tienen un papel muy secundario, a pesar de que en algunos casos son los ‘causantes' de los trágicos destinos de sus hermanas, esposas o madres.

\section{La construcción de la feminidad a través de los personajes}

A través del análisis realizado, podemos afirmar que los personajes femeninos tienen iniciativa y toman decisiones relacionadas con su vida o aspectos concretos de la trama ya que en las tres películas analizadas las mujeres aparecen como motores de las historias. Así, vamos a encontrar a personajes femeninos que toman decisiones tendentes a solucionar o darle salida a algún tipo de conflicto, como es el caso de Caridad en Habana Blues, Pepita en La voz dormida, o Rosa en Solas. En todos los casos son decisiones que van a afectar a su propia vida más allá del terreno afectivo. En el caso de Caridad y Rosa, su decisión está especialmente relacionada con uno de los personajes masculinos. La complejidad que presentan todos estos personajes 
en su caracterización se completa con su evolución a lo largo de la película y, de algún modo, su implicación en la evolución de los restantes personajes en cada uno de los relatos cinematográficos.

Por otro lado, en las tres películas llama la atención el papel que juegan los hombres en el relato, tanto en Solas como en La voz dormida. En este sentido, se podría hablar de una inversión de roles. Es decir, los personajes masculinos giran en torno a los femeninos y adquieren identidad en función de su relación con las protagonistas femeninas. En el caso de Habana Blues, los dos personajes principales son masculinos, pero el rol que van a jugar los personajes femeninos entorno a ellos va a ser decisivo en el desarrollo de la trama.

Asimismo, debemos destacar que las mujeres tienen escenas por sí solas al margen de su relación con los personajes masculinos. En La voz dormida es evidente las relaciones entre mujeres, entre las presas y Hortensia, o entre Pepita y doña Celia. En Solas, resalta la relación entre Rosa y María aunque la analizaremos en el apartado familiar. En Habana, no hay escenas al margen de los personajes masculinos, ya que, por ejemplo, en la escena en la que Caridad habla con su prima Betty terminan hablando de Ruy.

Relacionado con el apartado anterior, si hacemos una valoración de las relaciones de amistad, complicidad y afecto entre mujeres, teniendo en cuenta que no consideramos aquí las relaciones familiares -entre hermanas o entre madres e hijas- porque de ellas hablaremos a continuación, vuelven a destacar los personajes femeninos de La voz dormida, especialmente la relación entre las reclusas: Reme, Elvirita o Tomasa. En las otras dos películas no se dan estas relaciones entre mujeres.

Las familias que se representan en las tres películas están marcadas por conflictos motivados por diferentes razones -externas o internas- al propio núcleo familiar: violencia de género en Solas, represalias de la Guerra Civil en La voz dormida, lucha y supervivencia ante un futuro incierto en Habana Blues. Esto produce puntos de fricción y enfrentamientos entre algunos de sus miembros, amén de mostrar relaciones que distan de ser idílicas como la 
de Caridad y Ruy en Habana, o la de Rosa y su marido en Solas. Aún así, lo que sí se produce es un acercamiento progresivo entre madre-hija en esta última película. De nuevo tenemos que destacar la relación tan entrañable que existe entre las dos hermanas Hortensia y Pepita en La voz dormida.

En cuanto a las relaciones de pareja -consideramos pareja la estructura formada por dos miembros que mantienen una relación más o menos estable- podemos apreciar diversos estadios si nos movemos en la horquilla que se muestra a través de las tres películas: desde la relación inocente y noble entre Pepita y Paulino de La voz dormida, pasando por la relación de infidelidad entre Caridad y Ruy de Habana, hasta llegar a una relación de resignación y sometimiento por parte de Rosa ante su marido en Solas. También destaca la relación, en principio profesional, entre Ruy y Marta en Habana Blues, que aliñada con cierta tensión sexual, se convierte en un juego de seducción y encuentros fugaces, que termina con una ruptura profesional y personal.

Como hemos ido viendo el protagonismo recae en unos personajes femeninos complejos, cuya construcción presenta una multiplicidad de matices que los alejan de la representación estereotípica del cine patriarcal, donde el cine dejaba a la mujer sin salida.

Por último, hemos analizado la exigencia de un mínimo de representación femenina en el cine de Zambrano. Para ello, como ya hemos indicado en el apartado anterior, hemos utilizado el llamado test de Bechdel. De su aplicación deducimos que al contrario de lo que ocurre en Solas y en La voz dormida donde las protagonistas interactúan entre ellas y hablan de otros temas que no sean los hombres, en Habana Blues las tres mujeres protagonistas en ningún momento comparten escena, no existe ninguna conversación entre ellas. Las mujeres de Habana interactúan con los hombres, la abuela con Tito, Caridad con Ruy, y Marta, la productora con los dos. Incluso en sus parlamentos no hacen referencias a las otras mujeres que hay en la cinta, es como si no existieran. 
Las mujeres de los largometrajes de Benito Zambrano están perfectamente representadas, sobre todo en dos de las tres películas analizadas: Solas y La voz dormida. Es más, en estos dos largometrajes, las protagonistas casi absolutas son mujeres, mientras que en Habana Blues, aunque los protagonistas son dos hombres, aparecen tres figuras femeninas de vital importancia para el desarrollo de la trama.

\section{Conclusiones}

El análisis desarrollado ha permitido efectuar una aproximación a los personajes femeninos en tres de los largometrajes de Benito Zambrano. En sus películas las mujeres suelen corresponderse con personajes complejos que deben hacer frente a situaciones cotidianas, -como en Solas y Habana Blues-, y excepcionales, -como en La voz dormida- que distan mucho de ser ideales. Es decir, desde el punto de vista del personaje como persona estamos ante personajes redondos, contrastados y dinámicos.

Las protagonistas femeninas son personajes con diferentes arcos de transformación. Por ejemplo, Pepita en La voz dormida, sufre una evolución pareja a las difíciles circunstancias que le toca vivir. En Solas, es reseñable la evolución de María que pasa de ser una mujer frustrada a una mujer llena de sueños y esperanzas, y en Habana Blues, donde quizá la transformación es algo menor, ya que Caridad tiene las ideas muy claras de principio a fin, para ella lo más importante son sus hijos y tarda muy poco en tomar la decisión de abandonar Cuba para irse a Estados Unidos con su madre.

Además, Zambrano rompe con el catálogo de representaciones femeninas del llamado cine patriarcal y sus personajes presentan una construcción cargada de contrastes que los hacen más reales a los ojos de su público. Atrás quedan los roles que criticaba Haskell y que poco tenían que ver con la mujer real, en los que se jugaba con la dicotomía mujer buena/mujer mala, en la que, o bien se presentaba a la mujer como un ser bueno dentro del entorno domestico, o como algo malo, alejada de su entorno por su condición de mujer. 
Nuestro director, además, trata temas de gran calado social y aunque en las películas aparecen ambientes domésticos, el papel de la mujer se aleja del rol tradicional y su función va más allá de lo que se espera de éstas. Las protagonistas soportan familias imperfectas, fracasan en sus relaciones de pareja, viven situaciones laborales precarias o intentan superar situaciones límite, como es el caso de Pepita en La voz dormida. A partir del día a día de estas mujeres, Zambrano denuncia situaciones de soledad, desamparo, incomunicación o injusticia. Todas ellas son mujeres con vidas difíciles debido a circunstancias de las que muchas veces ellas no son responsables. Así mismo, nuestras protagonistas tienen un gran peso dentro de la institución familiar. Son mujeres como Rosa en Solas, Pepita en La voz dormida o Caridad en Habana Blues, las que se sacrifican y luchan por sacar a los suyos adelante, incluso se convierten en el sustento de los que las rodean, habitualmente hombres. Son mujeres con gran fortaleza, independientes, luchadoras y sufridoras.

Así mismo, en los tres largometrajes analizados las mujeres se presentan como el motor que hace que el relato narrativo avance, es decir, las mujeres dejan de ser únicamente el elemento erótico del espectáculo fílmico, el fetiche, como afirmaba Mulvey (1975), para convertirse en productoras de los sucesos. Por ejemplo, en el caso de Solas, Rosa, se presenta como el 'sujeto' que quiere ayudar ('fuerza actancial') a su hija María, que es el 'objeto'. Toda la película gira en torno a este hecho, al que se opone el propio 'objeto', es decir, el personaje de María, ya que se presenta como el origen de los conflictos del relato narrativo. El resto de elementos narrativos (destinador o ayudantes), en su mayoría hombres, pasan a un segundo plano. A modo de conclusión podemos corroborar el gran peso de las protagonistas femeninas en las tres películas analizadas de Benito Zambrano, dos de ellas protagonizadas íntegramente por mujeres, y la tercera mostrando a la mujer como el ejemplo que deberían seguir los hombres. 


\section{Referencias bibliográficas}

Arranz, Fátima; Roquero, Esperanza; Aguilar, Pilar; Pardo, Pilar, (2008). La situación de las mujeres y los hombres en el audiovisual español: estudios sociológico y legislativo. Madrid: Universidad Complutense.

Bechdel, Alison (1986). Dykes to watch out for. New York: Firebrand Books.

Berrocal, Joaquín Florido (2008). La Huella Psicológica del Franquismo en el Cine Español de los Noventa. En Working Papers in Romance Languages, vól 1, Issue I, Article 2. Berkeley: Berkeley Electronic Press. http://repository.upenn.edu/wproml/vol1/iss1/2

Bosch Fiol, Esperanza y Ferrer Pérez, Victoria Aurora (2003). Fragilidad y debilidad como elementos fundamentales en el estereotipo tradicional femenino. En Feminismo/s: revista del Centro de Estudios sobre la Mujer de la Universidad de Alicante, número 2.

Butler, Judith, (1990). El género en disputa. El feminismo y la subversión de la identidad. Barcelona: Paidós.

Casetti, Francesco y Chio, Federico di (2010). Cómo analizar un film. Madrid: Paídos.

Castejón Leorza, María (2004). Mujeres y cine. Las fuentes cinematográficas para el avance de la historia de las mujeres. En Berceo, núm. 147.

Castro Ricalde, Maricruz (2002). Feminismo y teoría cinematográfica. En Escritos (Revista del Centro de Ciencias del Lenguaje), núm. 25, pp. 23-48.

Colazzi, Giulia (1995). Feminismo y teoría fílmica. Valencia: Episteme.

Diez Puertas, Emeterio (2006). Narrativa filmica. Escribir la pantalla, pensar la imagen. Madrid: Editorial Fundamentos.

Domínguez Prats, Pilar (2003). Del modelo a la imagen de mujeres y hombres bajo el franquismo. En Nielfa Cristóbal, Gloria (ed.): Mujeres y hombres en la España franquista: sociedad, economía, política y cultura. Madrid: Editorial Complutense.

Greimas, A. J. y Courtes, J. (1982). Semiótica. Diccionario razonado de la teoría del lenguaje. Madrid: Gredos.

Guarinos, Virginia (2008). Mujeres en proyección. La mujer en el cine. Teorías feministas. En Loscertales Abril, Felicidad; Núñez Domínguez, Trinidad: La mirada de las mujeres en la sociedad de la información. Madrid, Visión Net.

Haraway, Donna J. (1991). A Cyborg Manifesto: Science, Technology, and Socialist-Feminism in the Late Twentieth Century. En Haraway, Donna, J. Simians, Cyborgs and Women: The Reinvention of Nature. New York; Routledge, 1991. p.149-181.

Haskell, Molly (1987). From Reverence to Rape. The Treatment of Women in the Movies. Chicago: University of Chicago Press. 
Hernandez Holgado, Fernando (2003). Mujeres encarceladas. La prisión de Ventas: de la República al franquismo, 1931-1941. Madrid, Marcial Pons.

Kaplan, E. Ann (1977). Interview with British cine-feminist. En Kay, Karin y Peary, Gerald, Women and the Cinema: a Criticat Anthology. New York: Dutton.

Kuhn, Annette (1991). Cine de mujeres. Feminismo y cine. Madrid, Cátedra.

Laguarda, Paula (2006). Cine y estudios de género: Imagen, representación e ideología. Notas para un abordaje crítico. En La algaba http://www.scielo.org.ar/scielo.php?pid=S166957042006000100009 \&script=sci_arttext Consultado, 2 de marzo de 2013.

Mulvey, Laura (1995). Pandora: topografías de la máscara y la curiosidad. En Colazzi Giulia, Feminismo y Teoría Fúlmica. Valencia: episteme. Pp.65-84.

Mulvey, Laura (1975). Placer Visual y cine narrativo. En Screen. Vól. 16, núm. 3. pp. 6-18.

Lanuza Avello, Ana (2012). Cine, mujer y cambio social: El lenguaje audiovisual de la democracia a través de la película Solas. En Gonzálvez Vallés, Juan Enrique; Cabezuelo Lorenzo, Francisco (coord.): La imagen del franquismo a través de la séptima arte: cine, franco y posguerra. Madrid, Visión libros.

Lauretis, Teresa (1987). Technologies of gender. Indiana: Indiana University press.

Lema Trillo, Eva Victoria (2003). Los modelos de género masculino y femenino en el cine de Hollywood, 1990-200o. Memoria para optar al grado de doctor presentada por Eva Victoria Lema Trillo. Universidad Complutense de Madrid.

Llorente, Lucia I. (2009). "Solas: retrato de una relación madre - hija", en Espéculo. Revista de estudios literarios, núm. 41, marzo-junio 2009. Facultad de Ciencias de la Información. Universidad Complutense de Madrid. ISSN:

http://www.ucm.es/info/especulo/numero41/solas.html

1139-3637.

Melini, Nicolás (2011). Impronta. Una cuestión etérea para cinco creadores (del cine y la literatura): Benito Zambrano, Fernando León Rodríguez, Ricardo Menéndez Salmón, Juan Carlos Chirinos y Alberto Morais. En El Rapto de Europa: crítica de la cultura, $\mathrm{n}^{0} 19$.

Mellen, Joan (1974). Women and their sexuality in the new films. New York: Laurel.

Oaknin, Mazal (2009). La reinscripción del rol de la mujer en la Guerra Civil española: La voz dormida. En Espéculo, núm. 43. 
Parrondo Coppel, Eva (1995). Feminismo y cine: Notas sobre treinta años de historia. En Revista Secuencias, núm. 3, pp.9-20.

Pino, Jose María del (2003). Ausencia de Sevilla: identidad y cultura andaluza en Solas (1999) de Benito Zambrano. En España Contemporánea. Revista de Literatura y Cultura, tomo 16, núm. 1, ISSN 0214-1396. pp.7-24.

Pozo, Diego del (2005). Habana Blues. En Chasqui núm. 34-2, noviembre.

Puebla, Belén y Carrillo, Elena (2011). La mujer en el cine de Alejandro Amenábar: pinceladas de una nueva feminidad en el cine español. En Razón y Palabra, núm 78.

Roca i Girona, Jordi (2003). Esposa y madre a la vez. Construcción y negociación del modelo ideal de mujer bajo el (primer) franquismo. En Nielfa Cristóbal, Gloria (ed.): Mujeres y hombres en la España franquista: sociedad, economía, política y cultura. Madrid: Editorial Complutense.

Rosen Marjorie (1973). Popcorn Venus: women, movies and the American dream. New York : Coward, McCann \& Geoghegan.

Rueda Palomas, Ma Victoria (2011). Habana Blues: La melodía de una ciudad. En Salvador Ventura, F. (ed.) Cine y ciudades. Imágenes e imaginarios en ambientes urbanos. Santa Cruz de Tenerife: Intramar Ediciones. 


\section{Anexo 1}

Imagen de la viñeta donde se expresan las reglas de Bechdel.



